\title{
NILAI KARAKTER \\ DALAM DONGENG JEPANG
}

\author{
N.K.B.Wiani ${ }^{1}$ I.K.Antartika ${ }^{2}$ D.M.S.Mardani ${ }^{3}$ \\ ${ }^{123}$ Jurusan Pendidikan Bahasa Jepang, Universitas Pendidikan Ganesha, Singaraja,Bali \\ e-mail: belawiani21@gmail.com \\ antartika.kadek@undiksha.ac.id desak.mardani@undiksha.ac.id
}

\begin{abstract}
Abstrak
Penelitian ini bertujuan untuk mendeskripsikan nilai karakter dalam dongeng Jepang yang ditinjau dari pembentukan pengetahuan moral, wujud perasaan moral dan wujud tindakan moral. Subjek yang digunakan dalam penelitian ini adalah empat buah dongeng Jepang yang berjudul Shita Kiri Suzume (SKS), Hanasaka Jiisan (HJ), Tsuru no Ongaeshi (TNO) dan Kasa Jizou (KJ). Keempat dongeng ini dipilih karena mengandung cerita tentang perilaku manusia yang baik dan tidak baik untuk diteladani. Penelitian ini merupakan penelitian deskriptif kualitatif. Metode pengumpulan data yang digunakan adalah metode simak dengan teknik lanjutan yaitu teknik catat. Teori mengenai karakter oleh Lickona (2015), konsep mengenai folklor oleh Danandjaja (2002), konsep mengenai dongeng oleh Putera (2015) serta teori semiotika oleh Lustyantie (2012) menjadi acuan dalam penelitian ini. Hasil dari penelitian ini yaitu nilai karakter dalam dongeng Jepang ini ditinjau berdasarkan pengetahuan moral, perasaan moral dan tindakan moral. Komponen pengetahuan moral lebih ditonjolkan pada perbuatan baik dan perbuatan buruk tokoh dalam cerita yang sesuai dengan hukum karma agama Buddha. Komponen perasaan moral ditunjukkan dengan dua buah nilai karakter, yaitu karakter kasih sayang dan rendah hati. Komponen tindakan moral ditunjukkan dengan tiga buah nilai karakter, yaitu karakter saling menolong, kerja keras dan berterima kasih/bersyukur. Tanda-tanda yang menunjukkan nilai karakter berhubungan dengan budaya yang dimiliki masyarakat Jepang.
\end{abstract}

Kata kunci: nilai karakter, dongeng Jepang, budaya Jepang

要旨

本研究の目的は、感情的、行為的に、存在する道徳に注意が払われる日本昔話にお ける教訓を論じことである。対象は、日本昔話『舌切り雀』、『花咲か爺さん』、

『鶴の恩返し』、『笠地蔵』の4つの話である。4つの昔話は、人間としてよい手本、 悪い手本となる。本研究は、定性的記述研究であり、データは試読した後描写箇所を 抽出した。2015年Lickonaによる教訓の理論、2002年Danandjajaによる民話の概念、 2015年Puteraによる童話の概念、2012年Lustyantieによる記号論の理論 は本研究の土台 となるものである。結果、4つの日本昔話に描かれる教訓は、感情的、行為的道徳観 が描かれている。紹介されている道徳観は、仏教の教えにもとずく説話の中で、善人 と悪人の行動として描かれている。感情的道徳観は、慈愛と謙虚の2種類、行為的道 徳観は、助け合い、感謝、勤勉の 3 種類が描かれている。教訓の内容は日本社会に 根付く伝統的文化関連したものである。

キーワード: 教訓、日本斮話、日本文化 


\section{Pendahuluan}

Karakter yang dimiliki manusia berbeda antara manusia satu dengan manusia yang lainnya. Membentuk karakter yang baik merupakan salah satu tujuan pendidikan selain membentuk individu yang cerdas dalam akademik. Karakter manusia dapat dibentuk dengan pendidikan karakter di sekolah ataupun di rumah. Mengenai pendidikan di Indonesia, Supardi (2015) berpendapat bahwa pendidikan di Indonesia masih terkesan hanya menciptakan sumber daya manusia (SDM) yang hanya cerdas dalam akademik, tetapi memiliki moral yang buruk.

Pendidikan yang hanya menciptakan individu yang cerdas dalam akademik akan menimbulkan ketidakseimbangan dalam pendidikan. Agar ketidakseimbangan dalam pendidikan tidak terjadi, diperlukan adanya pendidikan karakter yang dilaksanakan secara komprehensif dan bersifat holistik (Rukiyati, 2013). Terkait dengan pembentukan karakter, dongeng dapat dijadikan sebagai salah satu media dalam pembentukan karakter. Fitroh (2015) berpendapat bahwa dongeng dianggap salah satu bacaan yang mampu untuk menumbuhkan karakter individu dengan cara yang lebih menyenangkan serta membuat anak didik merasa terhibur.

Terkait dengan dongeng, setiap negara memiliki cerita dongeng yang beragam, begitu pula halnya dengan Jepang. Jepang memiliki banyak cerita dongeng yang bahkan telah diterjemahkan ke dalam berbagai bahasa. Karakter masyarakat Jepang juga sudah tidak diragukan lagi, terutama dalam hal kedisiplinan dan kerja keras. Kedisiplinan yang dimiliki masyarakat Jepang tersebut telah menjadi sebuah budaya di Jepang.

Cerita dongeng Jepang ditengarai sebagai salah satu cerita luhur yang berkontribusi pada karakter masyarakat Jepang saat ini. Hal tersebut karena dongeng Jepang mengandung nilai-nilai luhur yang membentuk karakter masyarakat Jepang. Dongeng Jepang yang dipandang memiliki nilai luhur dan pesan yang baik diantaranya yaitu Shita Kiri Suzume yang dalam tulisan selanjutnya ini disingkat SKS, Hanasaka Jiisan yang dalam tulisan selanjutnya ini disingkat $H J$, Tsuru no Ongaeshi yang dalam tulisan selanjutnya ini disingkat TNO dan Kasa Jizou yang dalam tulisan selanjutnya ini disingkat $\mathrm{KJ}$.

Keempat dongeng Jepang tersebut dipilih karena mengandung karakter yang baik untuk diteladani oleh pembaca. Keempat dongeng tersebut juga memiliki tokoh-tokoh yang bersifat baik dan buruk. Tokoh yang bersifat baik dan buruk akan membuat pembaca selain dapat memahami karakter yang baik untuk diteladani, juga memahami karakter yang tidak baik untuk diteladani. Selain itu, keempat dongeng tersebut juga menunjukkan interaksi antar manusia yang menimbulkan akibat yang sesuai dengan perbuatan manusia terhadap manusia lainnya tersebut. Penelitian ini juga akan meninjau konteks sosial budaya masyarakat Jepang, karena penelitian cerita rakyat dapat dikaitkan dengan konteks sosial masyarakat pemiliknya (Simatupang, 2011). Simbol dalam teks cerita rakyat juga merupakan cerminan simbolis masyarakat pemilik cerita, yang dalam penelitian ini adalah masyarakat Jepang. Berdasarkan latar belakang di atas, penelitian dengan judul "Nilai Karakter dalam Dongeng Jepang" ini dilakukan.

Kaitannya mengenai nilai karakter pernah dilakukan penelitian oleh Dewi (2016). Penelitian tersebut berjudul "Analisis Nilai Karakter Dongeng dalam Buku "Bahasa Indonesia untuk SD dan MI Kelas III" SDN Pandean Lamper 05 Semarang". Selain itu, penelitian yang juga menggunakan dongeng sebagai subjek penelitian yaitu penelitian oleh Zulfa (2017). Penelitiannya berjudul "Pesan Moral yang Tercermin dalam Dongeng Akai Neko Karya Okino Iwasaburou". Penelitian selanjutnya yang juga menggunakan kajian semiotika dilakukan oleh Kasriani (2016). Penelitian tersebut berjudul "Simbol dalam Cerita Rakyat Muna (Kajian Semiotik)". Penelitian kali ini akan melengkapi ketiga penelitian di atas dengan meneliti nilai karakter dalam empat buah dongeng Jepang yang berjudul SKS, HJ, TNO dan $K J$ yang ditinjau dari pembentukan pengetahuan moral, wujud perasaan moral dan wujud tindakan moral. Penelitian ini merupakan penelitian deskriptif kualitatif yang tujuannya untuk menjawab rumusan masalah, yaitu "Bagaimanakah nilai karakter yang digambarkan dalam 
empat buah dongeng Jepang yang berjudul SKS, HJ, TNO dan $K J$, ditinjau dari pembentukan pengetahuan moral, wujud perasaan moral dan wujud tindakan moral?"

\section{Pengertian Nilai}

Nilai adalah sesuatu yang sangat berguna dan bermanfaat bagi manusia. Karena itu, nilai juga dianggap sesuatu yang sangat penting bagi manusia. Semakin berguna suatu benda, maka akan semakin berguna, bermanfaat dan penting barang tersebut bagi manusia. Sudut pandang yang berbeda akan menyebabkan nilai dari sesuatu itu akan berbeda pula (Kosasih, 2012: 46).

Nilai juga dapat digunakan untuk mengukur segala sesuatu yang bersifat abstrak. Nilai yang bersifat abstrak ini dikemukakan dengan kata-kata. Karena keabstrakkannya itu, maka nilai dari pendapat atau pandangan satu orang mungkin berbeda dengan nilai dari pendapat atau pandangan orang lain.

\section{Karakter}

\section{Pengertian Karakter}

Karakter merupakan sifat-sifat kejiwaan, akhlak atau budi pekerti yang membedakan seseorang dari yang lain. Karakter seseorang terbentuk dari kebiasaan yang dilakukan individu yang akhirnya membuat karakter tersebut menempel pada individu. Menurut Ramli (2003: 41), pendidikan karakter itu memiliki esensi dan makna yang sama dengan pendidikan moral atau pendidikan akhlak. Tujuannya adalah membentuk pribadi anak didik agar menjadi pribadi yang baik.

Menurut Lickona (2015: 82), karakter memiliki tiga buah bagian yang saling berhubungan. Tiga bagian tersebut antara lain yaitu pengetahuan moral, perasaan moral dan tindakan moral. Lebih lanjut, diungkapkan pula bahwa karakter yang dianggap baik yaitu karakter yang ingin mengetahui segala hal yang baik, menginginkan sesuatu yang baik serta melakukan segala hal yang baik. Ketiga karakter yang baik tersebut dilakukan dalam suatu kebiasaan cara berpikir, berperasaan dan dalam tindakan. Ketiga bagian karakter tersebut akan membentuk seseorang yang memiliki karakter yang baik sehingga kehidupan bermoral pun akan terbentuk.

\section{Komponen Karakter yang Baik}

1. Pengetahuan Moral

Menurut Lickona (2015: 85), bagian karakter yang baik dalam pengetahuan moral terdiri atas enam buah aspek. Enam buah aspek tersebut merupakan tujuan pendidikan karakter yang diinginkan secara universal. Aspek-aspek tersebut antara lain yaitu kesadaran moral, mengetahui nilai moral, penentuan perspektif, pemikiran moral, pengambilan keputusan dan pengetahuan pribadi.

\section{Perasaan Moral}

Lickona (2015: 90-98) mengungkapkan bahwa perasaan moral merupakan sisi emosional karakter individu. Pengetahuan tentang moral tidak lengkap tanpa ada perasaan moral. Hal tersebut karena seberapa banyak peduli seseorang terhadap karakter baik akan mencerminkan seberapa banyak pengetahuan seseorang tentang pengetahuan moral untuk dilakukan. Perasaan moral terbagi atas enam aspek.

Aspek-aspek tersebut antara lain yaitu hati nurani, harga diri, empati, mencintai hal yang baik, kendali diri dan kerendahan hati.

\section{Tindakan Moral}

Tindakan moral menurut Lickona (2015: 98-100) merupakan hasil dari pengetahuan moral dan perasaan moral. Seseorang yang memiliki pengetahuan dan perasaan moral akan bisa melakukan apa yang dianggap benar dan baik. Tindakan moral terbagi atas tiga aspek. Aspek-aspek tersebut antara lain yaitu kompetensi, keinginan dan kebiasaan. 


\section{Folklor}

\section{Pengertian Folklor}

Folklor merupakan sebagian kebudayaan kolektif yang diwariskan secara turuntemurun secara tradisional, dalam bentuk yang berbeda-beda, baik secara lisan maupun gerak isyarat (Danandjaja, 2002: 1-2). Lebih lanjut, menurut Danandjaja (2002: 3-4), folklor memiliki ciri-ciri yaitu diwariskan secara lisan, bersifat tradisional, memiliki versi yang berbeda-beda, bersifat anonim, biasanya mempunyai bentuk atau pola yang sama, misalnya terdapat kata "konon". Ciri-ciri selanjutnya yaitu folklor mempunyai manfaat bersama, misal sebagai alat pendidik, bersifat pralogis, yaitu memiliki logika tersendiri yang berbeda dengan logika pada umumnya, milik bersama dari suatu kolektif serta bersifat polos dan lugu.

\section{Bentuk-bentuk Folklor}

Menurut Danandjaja (2002: 21), terdapat tiga buah bentuk folklor. Bentuk folklor pertama yaitu folklor lisan. Bentuk folklor kedua yaitu folklor sebagian lisan. Bentuk folklor yang ketiga yaitu folklor bukan lisan.

1. Folklor Lisan

Folklor berbentuk lisan merupakan folklor yang diwariskan secara turun-temurun secara lisan. Folklor ini terbagi lagi atas beberapa bentuk, diantaranya yaitu bahasa rakyat, ungkapan tradisional, pertanyaan tradisional, sajak dan puisi rakyat, nyanyian rakyat dan cerita prosa rakyat yang dibagi lagi dalam tiga bentuk, yaitu mite, legenda dan dongeng.

\section{Folklor Sebagian Lisan}

Danandjaja (2002: 153) mengungkapkan bahwa folklor sebagian lisan merupakan folklor yang menggabungkan bentuk lisan dengan bentuk bukan lisan. Folklor yang termasuk ke dalam bentuk sebagian lisan ada dua, yaitu kepercayaan rakyat dan permainan rakyat.

\section{Folklor Bukan Lisan}

Folklor bukan lisan merupakan folklor yang tidak disampaikan secara lisan. Salah satu contoh dari folklor bukan lisan adalah makanan rakyat.

\section{Dongeng}

Dongeng merupakan suatu cerita dunia hayalan dan imajinasi seseorang yang kemudian diceritakan secara turun temurun dari generasi ke generasi. Pesan moral yang terkandung di dalam dongeng mengandung berbagai ajaran bagaimana cara berinteraksi dengan makhluk lainnya (Putera, 2015: 35).

Menurut Lickona (2015, 124-125) secara tidak langsung, cerita merupakan bentuk lain dari suatu pengajaran moral. Pengajar moral di dunia cenderung lebih senang untuk menjadikan cerita sebagai salah satu instrumen pengajaran moral. Hal tersebut karena cerita dianggap memberi daya tarik serta lebih bersifat mengajak dibandingkan menggurui. Kekuatan dari sebuah cerita juga dianggap sesuatu yang alami untuk mengembangkan emosi dan karakter individu.

Mengenai dongeng di Jepang, Danandjaja (1995) mengungkapkan bahwa sebagian besar dongeng Jepang berasal dari China. Dongeng Jepang mulai dikumpulkan oleh para ahli cerita rakyat di Jepang pada tahun 1910. Selanjutnya, studi tentang dongeng di Jepang mulai dilakukan pada tahun 1930. Studi tentang dongeng Jepang tersebut juga digunakan sebagai media untuk menemukan karakter nasional dari masyarakat Jepang.

\section{Semiotika}

Salah satu tokoh semiotika yaitu Roland Barthes. Mengenai semiologi Barthes, Lustyantie (2012) mengungkapkan bahwa di dalam semiologi Barthes tersebut denotasi merupakan sistem signifikasi tingkat pertama, sementara konotasi merupakan tingkat kedua. 
Diungkapkan pula bahwa Barthes menolak adanya denotasi, dan menganggap yang ada hanyalah konotasi. Lebih lanjut dikatakan bahwa makna "sesungguhnya" merupakan sesuatu yang alami yang dikenal dengan teori signifikasi. Teori Barthes berlandaskan teori tentang tanda yang dikemukakan oleh Ferdinand de Saussure, hanya saja dilakukan perluasan makna dengan adanya pemaknaan yang berlangsung dalam dua tahap.

Menurut Lustyantie (2012), pemaknaan semiotika terjadi dalam dua tahap. Tanda (penanda dan petanda) pada tahap pertama menyatu sehingga dapat membentuk penanda pada tahap kedua. Pada tahap berikutnya penanda dan petanda yang telah menyatu ini dapat membentuk petanda baru yang merupakan perluasan makna. Petanda pada tahap kedua disebutnya konotasi, sedangkan makna tahap pertama disebut denotasi. Sebagaimana telah diuraikan di atas bahwa terjadi proses yang sama tetapi ada perbedaannya, yaitu bahwa setelah penanda dan petanda ini menyatu, yang muncul adalah tahap kedua yang berupa perluasan bentuk.

Semiotika dalam penelitian ini digunakan sebagai alat untuk menemukan tanda yang menunjukkan nilai karakter serta untuk memperkuat argumen ketika menganalisis tentang nilai karakter dalam empat buah dongeng Jepang yang digunakan dalam penelitian ini.

\section{Metode}

\section{Metode dan Teknik Pengumpulan Data}

Metode pengumpulan data yang digunakan dalam penelitian ini adalah metode simak. Menurut Mahsun (2013: 92), metode simak digunakan untuk memperoleh data dengan menyimak penggunaan bahasa. Istilah menyimak tersebut tidak hanya untuk penggunaan bahasa secara lisan, tetapi juga penggunaan bahasa secara tertulis.

Teknik lanjutan dari metode simak yang digunakan dalam penelitian ini adalah teknik catat. Mahsun (2013: 94) mengungkapkan bahwa teknik catat merupakan teknik mencatat beberapa bentuk yang relevan bagi penelitiannya dari penggunaan bahasa secara tertulis.

\section{Metode dan Teknik Analisis Data \\ Metode analisis data yang digunakan dalam penelitian ini adalah metode deskriptif kualitatif. Setelah menyimak dan menerjemahkan dongeng dengan seksama, data berupa kalimat-kalimat yang menunjukkan tanda nilai karakter (dengan bantuan semiotika) dalam dongeng SKS, HJ, TNO dan $K J$ disalin ke dalam kartu data nilai pendidikan karakter. Data tersebut kemudian dianalisis dengan menguraikannya ke dalam bentuk kata-kata. Karena penelitian ini berupa kualitatif maka perlu dilakukan penyusunan dan pengelompokan data yang ada, sehingga memberikan gambaran yang nyata (Sukardi 2003: 86). \\ Menurut Simatupang (2011), penelitian cerita rakyat secara tulisan dapat dilakukan dengan mengaitkan cerita rakyat tersebut dengan konteks sosial masyarakat pemiliknya. Hal tersebut karena simbol dalam dongeng merupakan cerminan simbolis masyarakat pemiliknya. Berdasarkan pendapat tersebut, karena penelitian ini meneliti nilai karakter berdasarkan tanda-tanda yang ditemukan dalam dongeng, maka penelitian ini juga meninjau konteks sosial budaya masyarakat pemilik, yaitu masyarakat Jepang. Nilai karakter yang ditemukan dalam keempat dongeng lalu dianalisis dengan dipaparkan secara deskriptif kualitatif. Terakhir, yaitu penarikan simpulan disesuaikan dengan hasil data yang diperoleh yang berkaitan dengan rumusan masalah penelitian. Simpulan inilah yang memberi jawaban atas masalah dalam penelitian yang dilakukan.}

\section{Hasil Dan Pembahasan}

Hasil penelitian ini yaitu ditemukan nilai karakter yang ditinjau dari pembentukan pengetahuan moral, wujud perasaan moral dan wujud tindakan moral. 


\section{Pengetahuan Moral}

Komponen karakter yang terkait dengan pengetahuan moral dalam cerita dongeng yang digunakan dalam penelitian ini lebih ditonjolkan dengan menguraikan pengetahuan moral tersebut ke dalam perbuatan yang baik dan perbuatan yang buruk. Pada dongeng SKS, terdapat pembentukan pengetahuan moral yang ditunjukkan oleh tokoh utama dalam cerita, yaitu tokoh kakek. Tokoh kakek menunjukkan bahwa dirinya memiliki pengetahuan moral dengan menunjukkan sikap-sikap yang positif. Salah satu bentuk pengetahuan moral yang ditunjukkan kakek adalah dengan kesadaran kakek melakukan sesuatu yang memiliki tujuan positif. Hal positif yang dilakukan oleh kakek adalah dengan sadar menolong burung gereja yang akan dimangsa oleh burung rajawali.

Pada dongeng $H J$, juga terdapat pengetahuan moral. Aspek pengetahuan moral dalam dongeng $H J$ adalah aspek penentuan perspektif. Kakek dalam dongeng $H J$ juga menunjukkan bahwa ia mampu merasakan situasi yang dialami kakek tetangga yang jahat. Kakek yang baik hati meskipun marah karena anjing dan lesung kesayangannya diperlakukan buruk, tetapi kakek tersebut tidak melampiaskan kemarahannya kepada kakek tetangga yang jahat. Kakek yang baik hati mampu merasakan kekesalan dan rasa kecewa yang dialami kakek tetangga yang jahat karena sesuatu yang diharapkan tidak tercapai. Hal tersebut menyebabkan hubungan antara kakek yang baik hati dan kakek tetangga tetap terjalin dengan baik.

Pada dongeng TNO, terdapat pula pembentukan pengetahuan moral yang menunjukkan aspek pemikiran moral. Hal tersebut ditunjukkan ketika si pemuda bersedia untuk menepati janji yang diminta oleh istrinya. Si pemuda merasa penting untuk dirinya menepati janji tersebut, sehingga ia menepati janjinya kepada sang istri. Burung bangau yang menyamar sebagai gadis cantik yang kemudian menjadi istri si pemuda juga menunjukkan aspek pemikiran moral. Hal tersebut karena burung bangau berpikir bahwa penting untuk membalas kebaikan pemuda yang menolongnya saat terluka.

Pada dongeng $K J$, menunjukkan aspek penentuan perspektif, yaitu ketika nenek mengetahui usaha kakek menjual topi jerami sampai sore tidak membuahkan hasil berupa uang tetapi nenek tidak marah. Tokoh dalam empat buah cerita dongeng yang berperan sebagai tokoh protagonis juga memahami dan mampu menerapkan nilai moral yang bersifat positif. Kakek dalam dongeng $K J$ menunjukkan bahwa ia mengetahui nilai moral dengan baik. Hal tersebut karena kakek tidak ragu untuk menolong enam buah patung batu yang tertutupi salju. Sikap kakek tersebut menunjukkan bahwa kakek tidak segan untuk mau menolong sesama, bahkan benda mati sekalipun, seperti patung batu.

Komponen pengetahuan moral pada aspek kesadaran moral, mengetahui nilai moral dan penentuan perspektif yang ditunjukkan dalam empat buah dongeng Jepang menunjukkan bahwa pengetahuan moral tersebut ditunjukkan dalam bentuk perbuatan baik dan perbuatan buruk. Perbuatan baik yang dilakukan akan memberikan dampak yang baik. Sebaliknya, perbuatan yang buruk juga akan memberikan dampak yang buruk.

Sacara lebih mendalam, pengetahuan moral merupakan komponen karakter yang juga menyebabkan munculnya perasaan moral dan tindakan moral. Pengetahuan moral dalam empat buah dongeng yang digunakan dalam penelitian ini juga menyebabkan munculnya perasaan dan tindakan moral oleh para tokoh. Berdasarkan hal itulah, secara tidak langsung pengetahuan moral merupakan pengetahuan yang memengaruhi perasaan dan tindakan yang dilakukan tokoh dalam cerita.

Menurut Simatupang (2011), penelitian cerita rakyat dalam tulisan juga dapat dilakukan dengan mengaitkan teks cerita rakyat dengan konteks sosial masyarakat pemilik cerita rakyat tersebut. Hal tersebut karena simbol-simbol dalam cerita rakyat juga merupakan cerminan simbolis masyarakat pemilik cerita rakyat tersebut. Berdasarkan pendapat tersebut, dongeng yang digunakan dalam penelitian ini juga akan dikaitkan dengan konteks sosial masyarakat pemilik cerita, yaitu masyarakat Jepang.

Menurut Danandjaja (1995), cerita rakyat di Jepang berasal dari China (sekarang Tiongkok). Buddha merupakan salah satu kepercayaan yang banyak dianut di Tiongkok, sekaligus merupakan kepercayaan yang banyak memengaruhi budaya di Tiongkok. Hal 
tersebut menyebabkan budaya yang ada di Jepang juga banyak dipengaruhi oleh kepercayaan Buddha, termasuk memengaruhi cerita dongeng di Jepang. Karena itu, perbuatan baik dan perbuatan buruk yang ditunjukkan dalam dongeng Jepang mendapatkan dampak yang sesuai dengan konsep hukum karma dalam kepercayaan agama Buddha.

\section{Perasaan Moral}

Perasaan moral merupakan komponen karakter yang timbul karena pengetahuan moral dan ditunjukkan dengan tindakan moral. Terdapat dua buah karakter yang sesuai dengan komponen karakter perasaan moral. Karakter tersebut yaitu karakter kasih sayang dan karakter rendah hati. Dua buah karakter yang ditemukan dalam penelitian ini dapat dilihat di bawah ini.

\section{Karakter Kasih Sayang}

Kasih sayang merupakan karakter yang menyayangi orang lain, maupun alam sekitar (binatang dan tumbuhan). Kata sayang juga berarti cinta kasih. Sayang merupakan sesuatu hal yang secara alami diperlukan oleh manusia dalam hidup. Seseorang perlu disayangi dan dicintai oleh orang lain. Karakter kasih sayang ditemukan pada dongeng SKS, HJ dan KJ. Karakter kasih sayang dalam dongeng $H J$ dapat dilihat pada kutipan di bawah ini.

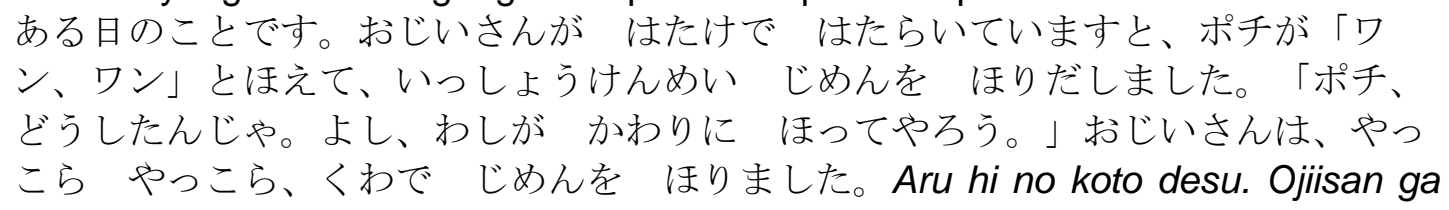
horidashimashita. "Pochi, doushitan jya. Yoshi, washi ga kawarini hotte yarou" ojiisan wa yakkora yakkora, kuwa de jimen o horimashita. (HJ, 2016: 2-4)

Pada suatu hari, ketika si kakek sedang bekerja di ladang, Pochi kemudian menggonggong dan menggali tanah dengan sungguh-sungguh. "Pochi... ada apa denganmu?? aku yang akan menggantikanmu menggali tanahnya...." kata si kakek yang melanjutkan mencangkul tanah tersebut.

Kasih sayang ditunjukkan oleh tokoh kakek kepada Pochi yang merupakan anjing peliharaannya dengan nenek. Kakek yang tidak memiliki anak kemudian memelihara Pochi dengan penuh kasih sayang. Kasih sayang kakek kepada Pochi ditunjukkan kakek ketika berada di ladang. Kakek yang menyayangi Pochi sangat kasihan terhadap Pochi yang mencoba menggali tanah. Kasih sayang kakek tersebut membuat kakek menggantikan Pochi untuk menggali tanah tersebut, meskipun kakek tidak mengetahui apa yang hendak digali oleh Pochi.

Tanda yang menunjukkan kasih sayang yaitu tanda berupa anjing. Anjing di Jepang disimbolkan sebagai kasih sayang dan kesetiaan. Hal tersebut tercermin dari cerita Hachiko, seekor anjing yang sangat setia terhadap majikannya. Kesetiaan Hachiko ditunjukkan dengan kesetiannya yang selalu mengantar majikannya pergi ke statsiun, lalu menunggu kepulangan majikannya setiap hari. Tidak hanya itu, Hachiko juga tetap menunggu kepulangan majikannya dan tidak mau makan meskipun majikannya tetap tidak pulang karena telah meninggal. Kesetiaan Hachiko tersebut mendapat penghargaan dengan dibangunnya patung Hachiko di depan stasiun Shibuya. Kesetiaan anjing di Jepang juga terlihat dengan banyaknya foto yang menunjukkan anjing yang tidur di atas kuburan yang ternyata kuburan tersebut adalah kuburan majikannya. Banyak dari anjing Jepang yang menunjukkan kesetiaannya sampai anjing-anjing tersebut juga mengorbankan nyawanya (Junko, 1972).

Anjing sebagai tanda kesetiaan dan kasih sayang menunjukkan sikap kakek yang sangat menyayangi Pochi, sehingga Pochi juga menjadi anjing yang setia. Anjing tersebut secara tidak langsung juga menunjukkan kasih sayang kakek terhadap Pochi. Seperti hukum karma yang memaparkan bahwa perbuatan yang baik akan menimbulkan dampak yang baik, maka sikap kakek yang memperlakukan Pochi dengan penuh kasih sayang juga 
berdampak baik. Dampak baik tersebut tetap dirasakan kakek meskipun Pochi sudah meninggal.

\section{Karakter Rendah Hati}

Karakter rendah hati merupakan suatu karakter yang menunjukkan sikap yang tidak sombong dan tidak angkuh atas apapun yang telah dimiliki. Karakter rendah hati ditunjukkan oleh kakek dalam dongeng SKS. Sikap kakek yang menunjukkan karakter rendah hati dapat dilihat pada kutipan di bawah ini.
ちょんの おとうさんは、つづらを 二つ
に、大きな つづらか、小さな つづらの どちらかを おもちください。」「わ
しは としょりだから、小さくて かるいほうが いい。」と、おじいさんは 小
さな つづらを かついで かえりました。Chon no otousan wa, tsuzura o futatsu mottekite, iimashita. "Omiyage ni, ookina tsuzura ka, chiisana tsuzura no dochira ka o omochi kudasai.". "Washi wa toshiyori dakara, chiisakute karuihou ga ii." to, ojiisan wa chiisa na tsuzura o katsui de kaerimashita. (SKS, 2016: 20-22)
Lantas ayah Chon datang membawa dua buah kotak dan berkata "Sebagai oleh- oleh, silahkan bawa yang mana saja, entah kotak besar atau kotak kecil". "Karena aku sudah tua, mungkin lebih baik jika aku membawa yang kecil dan ringan saja" jawab si kakek yang kemudian memikul kotak kecil itu pulang ke rumahnya.

Kakek yang berada di rumpun bambu rumah Chon menunjukkan karakter rendah hati. Tanda bambu bermakna karakter rendah hati. Menurut Yu (2007: 40), bambu menjadi simbol rendah hati karena memiliki batang yang ramping dan berongga yang kosong serta ringan, tetapi sangat kuat. Meskipun kosong, tetapi batang bambu ini dapat dimanfaatkan untuk berbagai hal.

Simbol karakter rendah hati dalam pohon bambu ini adalah contoh yang sangat baik untuk kepribadian individu. Bambu yang disimbolkan memiliki karakter yang baik ini sering digunakan sebagai topik dalam seni seperti kaligrafi di kawasan Asia Timur seperti Tiongkok dan Jepang. Sikap kakek juga menunjukkan kerendahan hati karena ketika kakek diberikan pilihan oleh-oleh, kakek memilih untuk membawa oleh-oleh berukuran kecil. Kakek tidak menunjukkan kesombongan dan keangkuhannya yang sudah menolong Chon dari burung rajawali. Hal tersebut menunjukkan bahwa kakek merupakan seorang yang rendah hati, seperti lambang dari pohon bambu.

\section{Tindakan Moral}

Tindakan moral merupakan komponen karakter yang dilakukan atas dasar pengetahuan dan perasaan moral. Tindakan moral terkait dengan perbuatan baik dan buruk yang dilakukan tokoh dalam cerita. Perbuatan tersebut akan mendapatkan dampak yang sesuai dengan perbuatan yang dilakukan. Dampak yang sesuai dengan perbuatan tersebut dalam ajaran agama Buddha dikenal dengan hukum karma. Buddha merupakan salah satu kepercayaan yang banyak dianut di Tiongkok, sekaligus merupakan kepercayaan yang banyak memengaruhi budaya di Tiongkok.

Terdapat tiga buah karakter yang sesuai dengan komponen karakter tindakan moral yang ditemukan dalam penelitian ini. Karakter tersebut yaitu karakter saling menolong, kerja keras dan berterima kasih/bersyukur.

\section{Karakter Saling Menolong}

Karakter saling menolong merupakan sebuah karakter yang memberikan bantuan kepada orang lain yang membutuhkan bantuan. Karakter saling menolong ditemukan dalam dongeng SKS, TNO dan KJ. Karakter saling menolong dalam dongeng KJ dapat dilihat pada kutipan di bawah ini. 


\begin{abstract}
おじいさんは、おじぞうさまのあたまの雪をはらい、持っていた五つのかさをかぶ せてあげました。しかし、おじぞうさまは六つ。かさが一つ足りません。おじいさ んは、自分がかぶっていた古い手ぬぐいをおじぞうさまにかぶせ、家に帰りまし

た。 Ojiisan wa ojizousama no atama no yuki o harai, motte ita itsutsu no kasa o kabusete agemashita. Shikashi, ojizousama wa muttsu. Kasa ga hitotsu tarimasen. Ojiisan wa jibun ga kabutteita furui tenugui o ojizousama ni kabuse, ie ni kaerimashita. (KJ, 2003: 29)

Kakek lalu membersihkan kepala patung batu dari salju, lalu memakaikan lima topi jerami yang ia bawa kepada lima patung batu. Tetapi, patung batu tersebut berjumlah enam buah. Masih kurang satu buah topi jerami lagi. Kakek kemudian memakaikan handuk yang ia pakai kepada patung batu terakhir, lalu pulang ke rumahnya.
\end{abstract}

Tanda yang mendukung karakter saling menolong pada kutipan di atas adalah tanda jerami. Jerami merupakan batang padi yang sudah mengering. Jerami sering dijadikan sebagai pakan ternak. Selain sebagai pakan ternak, jerami juga dapat dijadikan sebagai pupuk organik, alas kandang ternak serta dapat dijadikan sebagai kerajinan yang berguna (Sumardi, 2015). Kegunaan yang dimiliki jerami untuk orang lain juga menggambarkan bahwa kakek sebagai pembuat dan penjual topi jerami dalam dongeng $\mathrm{KJ}$ berguna bagi orang lain yang membutuhkan topi jerami tersebut.

Berdasakan hal tersebut, jerami yang dibuat menjadi topi oleh kakek dan nenek dapat berguna bagi enam buah patung batu. Jerami tersebut juga menggambarkan bahwa kakek merupakan seseorang yang berguna bagi yang lain, termasuk berguna bagi patung batu. Secara tidak langsung, patung batu juga tertolong dengan sikap kakek tersebut.

Masyarakat Jepang sebagian besar percaya terhadap patung batu. Bahkan, patung batu yang dipercaya masyarakat Jepang tersebut ada berbagai macam. Salah satunya yaitu patung batu bernama patung jizo yang diyakini merupakan patung yang identik dengan anak-anak. Jenis patung jizo pun beragam, tergantung pada kekuatan yang diyakini dari masing-masing patung. Roku Jizo merupakan salah satu jenis patung jizo, terdiri atas enam buah patung batu yang dipercaya memiliki kekuatan yaitu membimbing seseorang di alam baka untuk melewati enam jalan yang harus dilalui, yaitu neraka, hantu, binatang buas, iblis, manusia dan surga. Patung jizo tersebut biasanya dipakaikan pakaian dan topi agar hangat. Hal tersebut pula yang dilakukan tokoh kakek dalam dongeng $K J$ yang memakaikan topi jerami yang dibawanya kepada patung batu yang kakek temui. Sikap itu dilakukan kakek agar patung batu tersebut dapat sedikit terhindar dari salju yang saat itu turun.

\title{
Karakter Kerja Keras
}

Kerja keras dapat didefinisikan sebagai suatu semangat pantang menyerah yang diikuti keyakinan yang kuat dan mantap untuk mencapai cita-citanya. Karakter kerja keras ditemukan dalam keempat dongeng Jepang yang digunakan dalam penelitian ini. Karakter kerja keras dalam dongeng $S K S$ dapat dilihat pada kutipan di bawah ini.

$$
\text { おじいさんが、すずめが とおらなかったか、とききと、馬あらいさまは、 }
$$

「馬を あらった 水を、おけに 七はい のめば、おしえてやろう。」といい

ました。Ojiisan ga suzume ga tooranakattaka, to kikuto, uma arai sama wa "Uma o aratta mizu o, oke ni nanahai nomeba, oshiete yarou." to iimashita. (SKS, 2016: 14) Ketika si kakek menanyakan kepada Tuan pengembala kuda apakah ada burung gereja yang terbang melewatinya atau tidak. Tuan pengembala kuda pun menjawab "Jika Anda bisa meminum tujuh tong air yang telah saya gunakan untuk memandikan kuda, barulah saya akan memberitahu.".

Tanda yang menunjukkan kerja keras oleh tokoh kakek yaitu tanda kuda. Pada dongeng $S K S$, kuda merupakan binatang yang digembala oleh pengembala kuda. Air yang telah digunakan untuk memandikan kuda tersebut kemudian diminum oleh kakek sebagai bentuk tantangan yang diberikan pengembala kuda kepada kakek. Makna kerja keras yang 
ditandai oleh tanda berupa kuda tersebut karena kuda merupakan binatang yang disimbolkan sebagai binatang yang kuat. Pada kepercayaan orang Tionghoa, kuda merupakan simbol kecepatan, keberanian dan kekuatan (Mulyono dan Thamrin, 2008). Kekuatan kakek yang ditandai dengan kuda menunjukkan bahwa kakek adalah seorang pekerja keras.

\section{Karakter Berterima Kasih/Bersyukur}

Berterima kasih merupakan sikap mengucap syukur atau membalas budi setelah menerima kebaikan. Berterima kasih merupakan sesuatu yang tidak diwajibkan setelah menerima kebaikan, tetapi akan dirasa wajib dilakukan oleh penerima kebaikan. Rasa bersyukur merupakan kesadaran untuk berterima kasih atas hal-hal baik yang terjadi serta berarti juga menyediakan waktu untuk berterima kasih. Karakter bersyukur ditunjukkan oleh tokoh kakek dalam dongeng $H J$. Kutipan yang menunjukkan karakter bersyukur dapat dilihat di bawah ini.

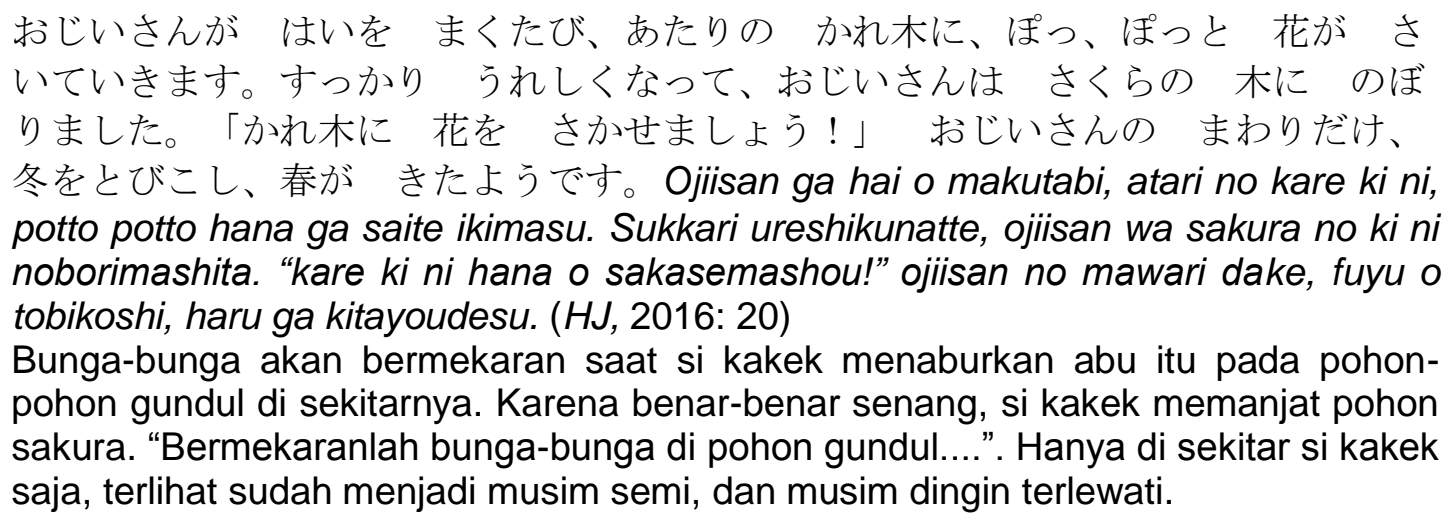

Bunga-bunga akan bermekaran saat si kakek menaburkan abu itu pada pohonpohon gundul di sekitarnya. Karena benar-benar senang, si kakek memanjat pohon sakura. "Bermekaranlah bunga-bunga di pohon gundul....". Hanya di sekitar si kakek saja, terlihat sudah menjadi musim semi, dan musim dingin terlewati.

Tokoh kakek dalam dongeng $H J$ menunjukkan karakter bersyukur ditandai dengan tanda bunga sakura. Bunga sakura merupakan bunga yang sangat istimewa di Jepang. Bunga sakura merupakan bunga yang mekar dalam waktu yang sangat singkat. Waktu yang singkat tersebut menggambarkan kehidupan yang singkat. Selain itu, sakura juga menggambarkan keindahan yang abadi (Atsushi, 2007). Hal tersebut mengajarkan untuk selalu bersyukur atas apapun yang telah terjadi dan apapun yang telah dimiliki. Karena itulah bunga sakura merupakan tanda yang menunjukkan karakter bersyukur. Karakter bersyukur yang ditandai dengan tanda bunga sakura dalam dongeng $\mathrm{HJ}$ ditunjukkan ketika kakek mensyukuri keindahan bunga sakura yang bisa ia ciptakan dengan abu sisa pembakaran lesung miliknya.

\section{Simpulan dan Saran}

Berdasarkan analisis nilai karakter pada penelitian ini, dapat disimpulkan bahwa dari keempat dongeng Jepang yang berjudul SKS, HJ, TNO dan KJ ditinjau pada tiga komponen karakter utama, yaitu pembentukan pengetahuan moral, wujud perasaan moral dan wujud tindakan moral. Pengetahuan moral lebih ditonjolkan pada perbuatan baik dan perbuatan buruk dari tokoh. Pengetahuan moral tersebut berdasar pada hukum karma pada ajaran Buddha. Hal tersebut mengakibatkan segala perbuatan tokoh mendapatkan dampak yang sesuai dengan perbuatan tersebut. Perasaan moral ditunjukkan dalam dua bentuk karakter, yaitu kasih sayang dan rendah hati. Tindakan moral ditunjukkan dalam tiga buah karakter, yaitu saling menolong, kerja keras dan berterima kasih/bersyukur. Nilai karakter tersebut ditunjukkan dalam beberapa tanda-tanda yang terdapat dalam empat buah dongeng Jepang tersebut. Tanda-tanda tersebut berhubungan dengan budaya yang dimiliki masyarakat Jepang. 
Hasil dari penelitian ini yaitu empat buah dongeng Jepang dalam penelitian ini mengandung nilai karakter yang berhubungan dengan budaya yang dimiliki masyarakat Jepang. Karena itu, dapat disarankan beberapa hal sebagai berikut : yang pertama, bagi pembaca, diharapkan dengan adanya penelitian ini, pembaca dapat meneladani berbagai nilai karakter yang terkandung dalam dongeng $S K S$, $H J$, TNO dan $K J$, serta mengimplementasikannya dalam kehidupan sehari-hari. Selain itu, pembaca juga sebaiknya terus menambah pengetahuan tentang berbagai dongeng, dan meneladani nilai karakter yang terkandung di dalamnya. Kedua, bagi pendidik dan orang tua, sebaiknya menambah pengetahuan tentang berbagai macam cerita dongeng, sehingga dongeng dapat dijadikan sebagai media penanaman karakter.

\section{Daftar Pustaka}

Atsushi, Awazura. 2007. "Perceptions of Ambiguous Reality-Life, Death and Beauty in Sakura". Japanese Religions, Vol. 32 (1 \& 2): 39-51.

Danandjaja, James. 1995. "A Comparative Study of Japanese and Indonesian Folklores". Southeast Asian Studies, Vol. 33, No. 3, December 1995.

Danandjaja, James. 2002. Folklor Indonesia. Jakarta: PT Pustaka Utama Grafiti.

Fitroh, S.F. dan E.D.N. Sari. 2015. "Dongeng sebagai Media Penanaman Karakter pada Anak Usia Dini”. Jurnal PG-PAUD Trunojoyo, Volume 2, Nomor 2, hal 76-149.

JCC Origami. 2011. Meaning of the Origami Crane. Tersedia pada www.jccc.on.ca/origamicranes/pdf/meaning of the origami crane .pdf (diakses pada tanggal 28 Desember 2017).

Junko, Fujino. 1972. The Dogs of Japan. The East, Vol. VIII No. 3, March 1972.

Kosasih, E. 2012. Dasar-dasar Keterampilan Bersastra. Bandung. Penerbit Yrama Widya.

Lickona, Thomas. 2015. Educating for Character Mendidik untuk Membentuk Karakter. Jakarta: PT Bumi Aksara.

Lustyantie, Ninuk. 2012. "Pendekatan Semiotik Model Roland Barthes dalam Karya Sastra Prancis" Artikel disampaikan dalam Seminar Nasional FIB UI. Fakultas IImu Budaya Universitas Indonesia 19 Desember 2012.

Mahsun. 2013. Metode Penelitian Bahasa : Tahapan Strategi, Metode, dan Tekniknya. Jakarta: Rajawali Pers.

Mulyono, Grace dan Diana Thamrin. 2008. "Makna Ragam Hias Binatang pada Klenteng Kwan Sing Bio di Tuban”. Dimensi Interior, Vol. 6, No. 1, Juni 2008: 1-8.

Putera, P.B. 2015. Mengenal dan Memahami Ragam Prosa Lama (Hikayat, Dongeng, Tambo dan Cerita Berbingkai). Yogyakarta: Graha IImu.

Ramli. T., 2003, Pendidikan Karakter. Bandung: Angkasa.

Rukiyati. 2013. "Urgensi Pendidikan Karakter Holistik Komprehensif di Indonesia". Jurnal Pendidikan Karakter, Tahun III, Nomor 2, Juni 2013.

Simatupang, G. R. Lono Lastoro. 2011. "Penelitian Cerita Rakyat”. Makalah disajikan dalam Kegiatan Peningkatan Mutu Tenaga Teknis Balai Bahasa Yogyakarta, di Hotel University, Sleman, 2-3 November 2011. 
Sukardi. 2003. Metodologi Penelitian Pendidikan. Jakarta: PT Bumi Aksara.

Sumardi. 2015. Melirik Kembali Jerami Padi. Tersedia pada http://tabloidsinartani.com/content/read/melirik-kembali-jerami-padi/ (diakses pada tanggal 28 Desember 2017).

Supardi. 2015. "Arah Pendidikan di Indonesia dalam Tataran Kebijakan dan Implementasi". Jurnal Formatif 2(2): 111-121, ISSN: 2088-351X.

Yu, Xiaobing. 2007. Bamboo: Structure and Culture. Yibin, China. 